$\left.\begin{array}{c}\text { Sournals } \\ \text { INTERNATIONAL JOURNAL OF } \\ \text { ORGANIZATIONAL LEADERSHIP }\end{array}\right) \begin{gathered}\text { INDUSTRIAL } \\ \text { MANAGEMENT } \\ \text { INSTITUTE }\end{gathered}$

\title{
Industrial conflict and its management in selected Nigerian manufacturing companies
}

\author{
Solaja Oludele Mayowa
}

University of Ibadan, Ibadan, Nigeria

\begin{abstract}
Keywords:

Labour-Management, Grievances, Strategies, Communication, Bargaining, Policies

Correspondence: solaja.mayowa777@yahoo. com

This study examined industrial conflict and its management strategies in selected manufacturing companies in Lagos State, Nigeria. The study utilized co-relational survey method which involves the use of structured questionnaire and personal observation to elicit information from the respondents. Participants comprised of staffs of three manufacturing companies in Lagos, Nigeria. Multistage sampling technique was employed in selecting the respondents from the three manufacturing companies under the study. The data collected were analyzed using descriptive statistic including tables, frequency counts, and percentages as well as mean scores. The findings revealed that the causes of conflict in manufacturing companies in Lagos State, Nigeria include poor means of communicating grievances to top managers, unfavorable economic and industrial policies, poor employee compensation and welfare among others. Therefore, this study concluded that managers should combine strategies such as bargaining, collaboration and avoidance when dealing with industrial conflict to maintain cordial and productive labour-management relationship.
\end{abstract}

(C)AIMI Journals

\section{Introduction}

Conflict remains inevitable situation in everyday life whether it would be with yourself, others, organization, or societies. Within organizational setting, conflict may arise from conflict between employers and employees over how revenue should be divided, how work should be done, how long and hard people should work (Ford, 2007). It can also occur as a result of incompatibility of needs, ideas, beliefs, values, or goals among people working as a team (Suliman \& Abdulla, 2005); however, the end results of conflict are not predetermined and it could either be good or bad. To many managers conflict is evil that must not be entertained in a team, organization, or social settings while others conceived it as a weapon to 
thrash out differences and promote unity among those that concerns it for the purpose of attaining a goal or objectives. The variation in perception of people to occurrence of conflict is because managers react differently to conflict situation which is also the reflection of their knowledge of the cause of conflict and its modes of management for achieving maximum productivity in workplace.

Studies have been conducted by many scholars on the issue of conflict to investigate and explain why conflict is inevitable in work organization and possible ways to manage it. However, constant changes in work system vis-à-vis demand of both employees and employers call for periodic study of conflict situation and its management strategies in contemporary workplace. To understand the multi-dimensionality of conflict in today's competitive business environment, attempt is made here to examine the works of scholars such as Ubeku (1975) who observed that conflict in organization is a consequence of enduring power struggle between workers and their employer over the control of various aspect of work, inequality in the distribution of proceeds of industry, job insecurity of the worker, and poor management control. Also, Fajana (2002) separated industrial conflict from other forms of conflict to refer to the powerlessness of the employers and employees to arrive at a common agreement on any issue connected with employers-employees' interactions. In addition, Ogunbameru and Oribabor (2000) conceived that industrial conflicts take place whenever there is conflict of interests and objectives in labor-management relations. Also, Alebiosu and Akintayo (2007) noted that industrial conflict emerges as a result of employers not taking into consideration the needs or request of their workers.

More explicitly, Benjamin and Hideaki (2004) reported that the reasons and motives of industrial conflicts can be widely classified into two categories, namely economic and noneconomic causes. The economic causes involves subjects relating to amends such as payment, award, allowances, and conditions for work, working hours, leave, and holidays without pay, and unfair layoffs and retrenchments. The non economic factors incorporate victimization of workers, poor treatment by staff members, compassionate strikes, political elements, indiscipline, etc. In addition, Deutsch and Coleman (2000) conflict is not a battle between the rational and irrational; however, the manner in which conflict is controlled establishes whether it is constructive or destructive. It is worth noting that conflict may increase and lead to unproductive results or conflict can be resolved and lead to quality final products. Therefore, learning to manage conflict is integral to high-performance work organization that aims to maximize productive outcomes through effective conflict resolution mechanism. In this regard, Blake, Shepard and Mouton (1964) identified three main strategies that parties can take into account in dealing with their conflict. These strategies include win-lose, lose-lose, and win-win approach.

The win-lose approach is the process by which a party coerce or persuade the other parties to accept their position or perception on the matter arising. It is a situation where one party gains and the other loses. The strategy is to have a conqueror that is superior and a vanquished who withdraws in shame, but who gets ready cautiously for the next round and in the long run, everyone loses. 
The lose-lose strategy is elaborated by smoothing over conflict or by obtaining the simplest cooperation. In such circumstance, each party acquires some of what it wants, and resigns itself to limited satisfaction.

The win-win approach is a conscious and sentient and organized make an effort to increase the goals of both parties through collaborative problem solving. The conflict is considered as a problem to be answered rather than a war to be won. The significant difference is that both parties are versus the problem, rather than we (one party) would be versus them (the other party). This method concentrates on the wants and restraints of both parties rather than focusing and stressing strategies created to conquer. They work together toward mutual and superordinate goals, i.e., ones that can only be achieved by both parties pulling together. Between the long term relationships among the parties and short term accommodations, there is stress on the quality of the long term relationships.

Communication tends to be open and direct rather than secretive and scheming. Intimidation and enforcement are forbidden and prohibited. The major premise is made that integrative agreements are attainable given the full range of resources present in the relationship. Attitudes and behaviors aimed to increase the trust and acceptance rather than an incensement of distrust and hostility. The win-win approach necessitates a very high degree of tolerance and ability in human relations and problem solving. However, this study set out to examine industrial conflict and its management strategies in selected Nigeria manufacturing companies in Lagos state, Nigeria.

\section{Statement of the Problem}

Labour-management relations is a strong indicator/yardstick of the industrial relations systems, whereby in itself is a subsystem of the national system. It is therefore important to stress that any slightest differences or grievance between labour and management will not only jeopardize the industrial relations systems, but the whole system of the entire society at large. The promotion of an enduring relationship between labour and management is therefore essential for harmonious industrial environment. In addition, to generate this, the use of effective strategy of conflict management becomes essential and pervasive in any organizational/industrial setting. Furthermore, the impact and consequences of unattended conflict in the workplace on employees and the organization (Dijkstra, 2006), would often argue for immediate attention to the resolution of the conflict rather than a careful and systematic (and invariably more time-intensive) approach to investigating the underlying causes of conflict. Mayer (1974), for instance, argues that if the causes of conflict are known and understood, a conflict map can be developed which could guide conflict resolution processes. Realizing and comprehending the various forces that inform conflict behavior, consequently authorizes the facilitator or manager with the opportunity and chance to expand a more collectively focused and nuanced approach for handling with the particular occurrence of conflict.

\section{Purpose of the Study}

The general objective of this study is to examine industrial conflict and its management strategies in selected Nigeria manufacturing companies in Lagos state, Nigeria. The specific 
objectives for the study are to investigate the major causes of conflict in the company understudy; to know the conflict management strategies that the organization understudies are using in solving conflict in the organization; and to find out the effective conflict management strategies in work organization.

\section{Research Questions}

Based on the above objectives of the researcher, it is apparently obvious and important that some researchable questions are needed; these questions are expected to be the basis upon which the above stated objectives can be achieved. However, the under listed questions are germane to this research work:

1) What are the major causes of conflict in the company understudy?

2) What conflict management strategies does manufacturing companies use?

3) What is the effectiveness of conflict management strategies in work organization?

\section{Significance of the Study}

This study becomes necessary in the sense that the causes of conflict across various organizations in the country, especially in manufacturing organization have become a matter of concern to all well-meaning Nigerian. In 2012, there was industrial conflict across the country over the issue of minimum wages and other working conditions of employment in which it affected the operational activities of many government parastatals and private organizations in both manufacturing and service industries. Secondly, this study will enable managers in manufacturing industry to have in-depth knowledge of causes of conflict and how to manage conflict in manufacturing industry not only in Nigeria but also across the world. So in essence, this study seeks to ensure smooth running of organizations and to enable the two sides (employers and workers) to work together harmoniously in pursuing and achieving organizational goals and objectives.

\section{Methodology}

The study took place in manufacturing companies in Ilupeju area, Lagos-State, Nigeria. The selected manufacturing companies in the study are listed below and Table 1 shows the study location distribution.

Table 1

Study Location Distribution

\begin{tabular}{ccl}
\hline S/N & Companies & \multicolumn{1}{c}{ Address } \\
\hline 1 & Glaxosmithkline Nigeria & 1, Industrial Avenue, Ilupeju, Lagos State. \\
2 & PZ Industries Plc & 45/47 Town Planning Way Ilupeju Industrial Estate, Lagos State \\
3 & Nestle Nig Plc & 22/24 Industrial Avenue, Ilupeju, Lagos State \\
\hline
\end{tabular}

The research utilized co-relational survey method because it focused on people, the vital facts of people, and their beliefs, opinions, attitudes, motivation, and behavior. The design, therefore, identified conflict as a phenomenon which has already occurred and no attempt is made in this study to manipulate or control it. The population of study covered the entire staff 
of the three selected companies, namely GlaxoSmithKline Nigeria, PZ Industries Plc, and Nestle Nigeria Plc and the study population was divided into two categories including senior staff and junior staff. Table 2 presents the population distribution.

Table 2

Population Distribution

\begin{tabular}{ccc}
\hline Companies & & Population \\
\hline GlaxoSmithKline Nigeria & Senior staff & 72 \\
& Junior staff & 227 \\
PZ industrial Plc & Senior staff & 89 \\
& Junior staff & 192 \\
Nestle Nigeria Plc & & 94 \\
& Senior staff & 208 \\
Total & Junior staff & 882 \\
\hline
\end{tabular}

The sample size was two hundred and thirty-four (234) respondents that were scientifically selected through multistage sampling technique. Multistage sampling technique that consists of purposive stratified and simple random sampling techniques was used in this study. The researcher purposively selected three manufacturing companies operating in Ilupeju area of Lagos State and then used stratified sampling to group the workers in the selected companies into departments. Then, simple random technique was used to chose six departments, namely accounting department, personal/human relation department, legal department, operation department, purchasing department, and Security department while the simple random sampling was further used to select thirteen respondents from the six departments in each of the companies understudy making up two hundred and thirty-four (234) respondents.

The study adopted primary and secondary methods of data collection. The primary method was used to elicit information from the respondents while the secondary method which includes retrieving informal from textbooks, journals, articles, and internet was used to provide evidence for discussion of findings. A well structured questionnaire consisted of thirty questions which included close and open ended questions was used for primary data collection. The questions were carefully considered and structured in relevance to data needed. There were two sections; section A comprised of personal demographic data and section B comprised of questions on the research topic in the questionnaire. Also, the choice of using questionnaire hinged on the fact that majority of staff can read and write without any ambiguity.

The content validity of the research instrument (questionnaire) was determined through the efforts and opinions of the experts of tests and measurement. The reliability of the items was determined through a test-retest method of the research instrument. This enabled the researcher to ensure the consistency among data.

The questionnaire was administered by the researcher with three research assistants and the obtained data was analyzed using descriptive statistic which includes tables, figures, mean score, frequency and percentage. This was achieved through statistical package for the social sciences (SPSS). 
According to Babbie (1998), ethnical principles comprise the consideration for voluntary participation, anonymity, and confidentiality. These principles were strictly observed in the course of this study. The prospective respondents were notified that if they decided not to participate, they were free to withdraw their consent and to discontinue participation at any time. In addition, authorization was sought from the authority of the university to be considered and also from the respondents of this study; so that information obtained were reliable in line with the objectives of the study. Information obtained from the respondents was used for academic purpose while the identities of the respondents were kept anonymous and strictly confidential.

\section{Results}

The demographical variables of the respondents including age, sex, marital status, religion, educational qualification, occupational level, and length of service are presented in Table 3.

Table 3

Demographic Variables of the Respondents

\begin{tabular}{|c|c|c|c|}
\hline Variables & Options & Frequency & Percentages (\%) \\
\hline \multirow[t]{3}{*}{ Sex } & Male & 131 & 60.6 \\
\hline & Female & 85 & 39.4 \\
\hline & Total & 216 & 100.0 \\
\hline \multirow[t]{5}{*}{ Age } & Under 20 years & 39 & 18.0 \\
\hline & 20-30years & 85 & 39.4 \\
\hline & 31-40years & 47 & 21.8 \\
\hline & 41yrs and above & 45 & 20.8 \\
\hline & Total & 216 & 100.0 \\
\hline \multirow[t]{6}{*}{ Marital Status } & Single & 57 & 26.4 \\
\hline & Married & 109 & 50.5 \\
\hline & Separated & 32 & 14.8 \\
\hline & Widowed & 14 & 6.5 \\
\hline & Divorced & 4 & 1.8 \\
\hline & Total & 216 & 100.0 \\
\hline \multirow[t]{5}{*}{ Education Qualification } & WASCE & 19 & 8.8 \\
\hline & OND & 59 & 27.3 \\
\hline & HND/ B.Sc (Degree) & 102 & 47.2 \\
\hline & Msc/MBA & 36 & 16.7 \\
\hline & Total & 216 & 100.0 \\
\hline \multirow[t]{3}{*}{ Religion } & Christian & 147 & 68.1 \\
\hline & Islam & 69 & 31.9 \\
\hline & Total & 216 & 100.0 \\
\hline \multirow[t]{4}{*}{ Length of Service } & 1-5years & 73 & 33.8 \\
\hline & 6-10years & 96 & 44.4 \\
\hline & 11years and above & 47 & 21.8 \\
\hline & Total & 216 & 100.0 \\
\hline \multirow[t]{5}{*}{ Occupational Status } & Junior Staff & 63 & 29.2 \\
\hline & Supervisory Staff & 51 & 23.6 \\
\hline & Senior Staff & 65 & 30.1 \\
\hline & Management Staff & 37 & 17.1 \\
\hline & Total & 216 & 100.0 \\
\hline
\end{tabular}

The analysis in Table 3 shows the demographic characteristics of the respondents. The results displayed that $60.6 \%$ were males and $39.4 \%$ were females; this consideration implies that males engage in paying jobs more than the females and thus majority of the respondents were males. The age distribution of the respondents revealed that $18.0 \%$ were below 20 years, $39.4 \%$ were within $20-30$ years, $21.8 \%$ were within $31-40$ years while $20.8 \%$ were 
within 41years and above. This result indicated that majority of the respondents fell within the age 20-30 years; it also highlighted the fact that people within the 20-30 years had the passion to engage in work activities to meet their personal goals and aspirations of life. The marital status of the respondents showed that $26.4 \%$ were single, $50.5 \%$ were married, $14.8 \%$ were separated, and $6.5 \%$ were widowed while $1.8 \%$ was divorced. This result illustrated that majority of the respondents were married and this supported the fact people after securing job opportunities with stable income tend to get married, settle down and set up a family.

Furthermore, the educational qualifications of the respondents depicted that $8.8 \%$ were WASCE holders, $27.3 \%$ were OND holders, $47.2 \%$ were B.Sc/HND holders while $16.7 \%$ were M.Sc/MBA holders. These results revealed that majority of the respondents were HND/B.Sc (degree) holders and demonstrated the intellectual abilities, potentials, and the validity of the information provided by the respondents. The religion distribution by the respondents illustrated that $68.1 \%$ were Christian while $31.9 \%$ were Muslim. These result established that majority of the respondents practiced Christianity and it is an indicator that most Nigerians practice Christianity. The length of service of the respondents revealed that $33.8 \%$ worked for $1-5$ years, and $44.4 \%$ and $21.8 \%$ worked for $6-10$ years and for 11 years and above, respectively. These results depicted that most of the respondents worked for about 1-5 years in the organization. The occupational status of the respondents showed that $29.2 \%$ were junior staffs, $23.6 \%$ were supervisory staffs, and $30.1 \%$ were senior staffs while $17.1 \%$ were management staffs. These results showed that majority of the respondents were senior staffs.

The analysis was carried out in accordance with the research questions. In each case, the responses to the questions of the questionnaire were scored and the mean and standard deviation were determined. A mean response cut-off score 2.50 (i.e. $(4+3+2+1) / 4$ was adopted. Responses to the various questions were obtained from the analysis of statement and the results are shown in Table 4.

Table 4

Causes of Conflict in Manufacturing Organization

\begin{tabular}{|c|c|c|c|}
\hline $\mathrm{S} / \mathrm{N}$ & Responses & Mean & SD \\
\hline 1 & Unacceptable terms of employment such as poor hours of work, poor salary and lack of fringe benefits & 2.61 & 1.18 \\
\hline 2 & Poor human relations between management and employees & 2.78 & 0.88 \\
\hline 3 & Non consultation with employees before key decisions affecting them are taken & 2.67 & 0.93 \\
\hline 4 & Perceived autocratic style of managers & 2.81 & 1.13 \\
\hline 5 & Anti-union posture of management & 2.54 & 0.86 \\
\hline 6 & Poor decentralization of decision making and workers non representation in management & 2.74 & 0.87 \\
\hline 7 & Cumbersome and ineffective means of communicating grievances to top managers & 2.85 & 1.22 \\
\hline 8 & Lack of effective mechanism for prevention of conflict & 2.63 & 1.44 \\
\hline 9 & Poor government economic and industrial policies & 2.97 & 1.01 \\
\hline
\end{tabular}

The results in Table 4 depicted the mean score and the standard deviation respectively on the causes of conflict in manufacturing organization. The results showed that the sources of conflict in the manufacturing organization were diverse and cut across unacceptable employment terms, work conditions, perceived improper styles of management by the officers, and ineffectiveness means of grievance communication. It was revealed that the main sources of conflict in the organization were related to ineffective means of communicating grievances to top managers, poor government economic and industrial 
policies, the specific issues bother on employee compensation, welfare, and inadequate communication. The findings corroborated Ubeku (1975) and Alebiosu and Akintayo (2007) who reported that conflict in organization is attributable to an enduring power struggle between workers and their employer over the control of various aspects of work, inequality in the distribution of proceeds of industry, job insecurity of the worker, and poor management control strategies breed grievances which led to conflict. Table 5 illustrates the strategies for conflict management in manufacturing organization.

Table 5

Strategies for Conflict Management in Manufacturing Organization

\begin{tabular}{|c|c|c|c|}
\hline $\mathrm{S} / \mathrm{N}$ & Responses & Mean & SD \\
\hline 1 & Consulting with workers in order to resolve the conflict & 2.61 & 1.08 \\
\hline 2 & Putting machineries in place to address the sources of conflict & 3.41 & 0.85 \\
\hline 3 & Effecting necessary changes in process and procedure management & 2.78 & 0.67 \\
\hline 4 & Putting in place a formal procedure for conflict Prevention so as to avoid future conflict & 2.63 & 1.12 \\
\hline 5 & Intimidation of workers & 2.97 & 0.84 \\
\hline 6 & Enforcing strict disciplinary rules on workers & 2.61 & 0.98 \\
\hline
\end{tabular}

The results in Table 5 revealed the mean and standard deviation of the data elicited on strategies for conflict management in manufacturing organization. The analysis showed that strategies for conflict management were diverse and varied from one organization to another. It was further found that the managers prefer the compromise, problem solving and dominating strategies such as putting machineries in place to address the sources of conflict, intimidation of workers, and effecting necessary changes in process and procedure management. The finding tallies with Blake, Shepard, and Mouton (2004) who identified three general strategies for dealing with conflict, namely win-lose, lose-lose and win-win that parties may take to resolution. In addition, Butler (1973) reported that negotiators use integrating, obliging, or avoiding style more effective than those who use dominating style. Table 6 shows the effect of conflict management strategies in work organization.

Table 6

Effects of Conflict Management Strategies in Work Organization

\begin{tabular}{clcc}
\hline S/N & \multicolumn{1}{c}{ Responses } & Mean & SD \\
\hline 1 & Improved profitability & 2.83 & 1.01 \\
2 & Improved quality of service & 2.63 & 1.12 \\
3 & Better human relations between management and staff & 2.97 & 0.87 \\
4 & Reduced incidence of conflicts & 2.68 & 1.12 \\
5 & Less disruptions in manufacturing activities & 2.97 & 0.93 \\
6 & Less wastages in time and resource usage & 3.02 & 1.03 \\
7 & Reduced late coming and absenteeism & 2.96 & 0.93 \\
8 & Less delays in task performance & 2.65 & 0.79 \\
\hline
\end{tabular}

The results in Table 6 presented the mean and standard deviation of the data gathered on the effects of conflict management strategies in manufacturing organization. The results showed that good conflict management strategies promoted better labour-management relations, fewer disruptions of work activities, and improved profitability. The results also showed that the conflict management strategies in place at the organization were relatively useful in minimizing the incidence of disruptive conflicts while conflict management strategies had positive impacts on workers' productivity. The findings confirmed Alebiosu 
and Akintayo (2007) and Parker (1974) who argued that if conflict arise and are not managed properly will lead to delay of work activities, disinterest, and low employee productivity or action and in extreme cases it might lead to complete breakdown of the group or organization.

\section{Discussion and Conclusion}

The current study was a comparative analysis of conflict and its management strategies in some selected Nigerian manufacturing companies in Ilupeju, Lagos state, Nigeria. The study established that conflict arises from various sources and is inevitable in organizational settings. It also highlighted conflict management strategies such as dominance, avoiding, smoothing and compromising, hierarchical decision making and appeal procedure as voluntary means of conflict settlement in an organization using three manufacturing companies, namely GlaxoSmithkline Nigeria, PZ industries Plc and Nestle Nigeria Plc, Ilepeju, Lagos, Nigeria as a case study.

The study adopted correlational survey design using the ex-port facto type to establish the relationship between conflict and its management strategies in work organization. Two hundred and sixteen respondents were selected for the study using multi-stage sampling technique. A well-structured questionnaire was generated for the study and the elicited information was analyzed using t-test.

The finding of the study reviewed that the main sources of conflict in the selected organizations were due to ineffective means of communication of grievances to top managers, poor government economic and industrial policies, and poor employee compensation and welfare. The managers utilized combination of conflict management strategies such as compromising, namely putting machineries in place to address the sources of conflict, intimidation of workers and effecting necessary changes in process and procedure management. Besides, they took advantage of problem solving and dominating strategies. In addition, the results indicated that good conflict management strategies promote better labour-management relations, less disruption of work activities, and improve profitability. The most commonly used strategies for managing conflict among the managers in the selected Nigerian manufacturing companies were bargaining, collaboration, and avoidance.

In the light of the results, a series of recommendations are presented: Managers should develop diverse but appropriate strategies to resolve and manage conflicts as they arise before escalating to unmanageable level; efforts should be made by the managers to occasionally stimulate conflict by encouraging divergent views and rewarding staff and unit/department for outstanding performance; and proper communication procedures should be put in place to resolve conflict. For instance, when any disagreements arise among the employees, it should be reported to the management and then management should get statements from the parties involved, brainstorm the issue, and make recommendation on how to resolve the conflict.

Following this, efforts should be made by the management to organize seminars/workshops on organizational conflict management from time to time for the employees. This will enable employees to learn about conflict and how it can be effectively managed for individual and organization effectiveness. Lastly, group interaction and activities should be followed up so as to ensure a degree of functionality compatible to 
conflicts. Positive conflicts will only be possible if particularities of the organization are analyzed.

\section{References}

Alebiosu, K. A., \& Akintayo, D. I. (2007). Readings in industrial relations: Theory and practice. Ogun State University, Ago-Iwoye: Publication of the Institute of Education.

Babbie. E. R. (1998). The practice of social research ( $8^{\text {th }}$ Edition). Belmont, CA: Wadsworth Publication.

Benjamin, C. R., \& Hideaki, O. (2004). Collective bargaining and employee participation in Western Europe. London School of Economics.

Blake, R. R., Shepard, H. A., \& Mouton, J. S. (1964). Managing intergroup conflict in industry.Houston, Texas: Gulf.

Butler A. G. (1973). Project Management: A study in organizational conflict. Academy of Management Journal, 16(1), 84101.

Deutsch, M., \& Coleman, P. T (2000). The Handbook of Conflict Resolution: Theory and Practice (2 ${ }^{\text {nd }}$ ed.). San Francisco, CA: Jossey-Bass.

Dijkstra, M. T. M. (2006). Workplace conflict and individual well-being (Unpublished doctoral dissertation). University of Amsterdam, Netherlands.

Fajana, S. (2002). Industrial relations in Nigeria: Theory and features ( $2^{\text {nd }}$ Edition $)$. Lagos: Labofin and Company.

Ford, J. (2007). Organizational conflict management. What's a system? www.mediate.com/pfriendly. cfm?id=1250 (assessed 4 April, 2010).

Ogunbameru, O. A., \& Oribabor P. (2000). Introduction to industrial Sociology. Ile-Ife: Obafemi Awolowo University Press.

Mayer, B. (2000). The dynamic of conflict resolution. San Francisco: Jossey-Bass.

Parker J. (1974). Some ideas about working with people individually and in groups. Ohio Cooperative Extension Service.

Suliman, A. M., \& Abdulla, M. H. (2005). Towards a high-performance workplace: Managing corporate climate and conflict. Journal of Management Decision, 43(5), 720-733.

Ubeku. A. (2002). Personnel management in Nigeria. Benin City: Ethiopia Publishing Cooperation. 